\title{
Treefrog Dendropsophus elegans (Wied-Neuwied, 1824) (Anura: Hylidae) as a meal to Otostigmus tibialis Brölemann, 1902 (Chilopoda: Scolopendridae) in the Tropical Rainforest in southeastern Brazil
}

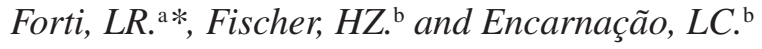

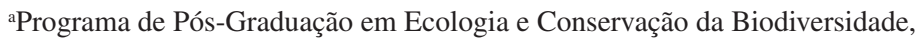 \\ Instituto de Biociências, Universidade Federal de Mato Grosso, \\ Av. Fernando Corrêa da Costa, s/n, CCBS-II, Boa Esperança, CEP 78060-900, Cuiabá, MT, Brazil \\ bDepartamento de Ciências do Ambiente, Centro de Ciências Médicas e Biológicas, \\ Pontifícia Universidade Católica de São Paulo, \\ Praça Dr. Ermírio de Morais, 290, Lageado, CEP 18030-230, Sorocaba, SP, Brazil \\ *e-mail: lucas_forti@yahoo.com.br \\ Received June 8, 2006 - Accepted July 17, 2006 - Distributed August 31, 2007
}

(With 1 figure)

\begin{abstract}
Arthropods are very important components of the amphibian diet (Santos et al., 2004) and among them, centipedes are constantly preyed on for many vertebrate groups (Biavati et al., 2004; Losos et al., 1991; Stancampiano and Caire, 1995). On the other hand, several arthropod species are important predators of vertebrates (Carpenter and Gillingham, 1984; McCormick and Polis, 1982).

Most arthropods that attack amphibians usually eat their eggs or larvae (Formanowicz, Jr. et al., 1981). However, there are others, like the water bug Belostoma elongatum that was registered by Toledo (2003) hunting nine adult amphibian species. Amphibians can also be preyed upon by arachnids (Castanho and Rocha, 2005; Menin et al., 2005) or centipedes (Carpenter and Gillingham, 1984). The gigantic Scolopendridae can also attack lizards, serpents, birds and bats (Molinari et al., 2005).

There are ten centipede species in Brazil whose bites are feared and some of them are known for causing accidents with humans (Barroso et al., 2001). This paper reports the predation of Dendropsophus elegans (Wied-Neuwied, 1824) (Anura, Hylidae) by a Scolopendridae next to a pond in the private reserve "Parque do Zizo", in the municipality of São Miguel Arcanjo, in the State of São Paulo, Southeastern Brazil. The place is about $650 \mathrm{~m}$ above sea level, and the climate of this region is warm and wet without drought (Morellato and Haddad, 2000).

Dendropsophus elegans occurs in the Atlantic Forest from Bahia to Parana up to $800 \mathrm{~m}$ of elevation (Frost, 2004). The males are approximately $26 \mathrm{~mm}$ in length and can maintain reproductive activity for several months, usually during the rainy season (Bastos and Haddad, 1996). Generally the vocalization activity begins about $30 \mathrm{~min}-$ utes before sunset and may continue until 5:00 A.M. of the following day (Bastos and Haddad, 1995).

The individual that attacked the treefrog belongs to the genus Otostigmus, which has a global distribution, including Africa, Oceania, India, Japan and America (Machado, 2000). The natural history of this genus and also of the order Scolopendromorpha is poorly known,
\end{abstract}

but cases of maternal care have been registered in some species (Machado and Chagas-Júnior, 2002). This genus was one among three others that received special attention of Knysak et al. (1998) for their epidemiological aspects in the municipal district of São Paulo, southeastern Brazil. Otostigmus tibialis Brölemann, 1902 occurs in São Paulo, Parana and Amazonas states and is the biggest species of the genus (Bücherl, 1939).

The predation was observed on February $21^{\text {st }}, 2006$, at about 9:00 pm. $\left(20.5^{\circ} \mathrm{C}\right.$ air temperature and $92.5 \%$ R.H.), by two of the authors (L.R.F. and L.C.E.), who saw a centipede of about $86 \mathrm{~mm}$ long next to a pond on a brick wall $50 \mathrm{~cm}$ high with the treefrog in its maxillipeds. The centipede was on the treefrog (Figure 1)

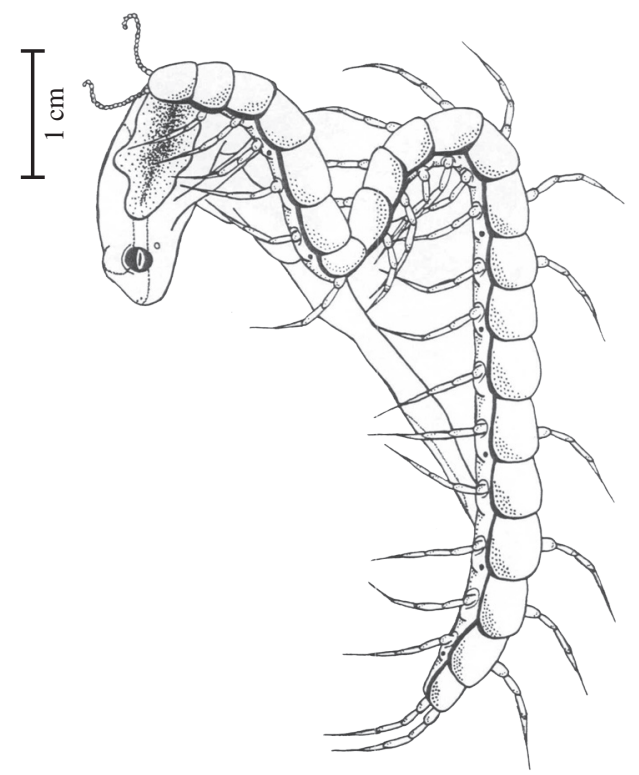

Figure 1. Otostigmus tibialis preying on recently-dead Dendropsophus elegans; 
and used the first 5 to 6 pairs of legs to hold the prey that was already dead, and the first two were also used as support for the lateral left opening made in the victim. After opening the prey, the centipede apparently began to ingest the internal contents. Elzinga (1994) observed the use of the first 7 to 8 pairs of legs of Scolopendra viridis during the preying behavior on a cockroach, Periplaneta americana. He also observed a relationship between the number of legs used and the prey size. Scolopendra gigantea used 7-8 pairs of legs to hold bats and also for cutting its abdominal area in a Venezuelan cave (Molinari et al., 2005). The abdominal cutting was reported by Carpenter and Gillingham (1984) during the attack of a centipede to an adult Chaunus marinus, however this frog was still alive after the interaction.

As we did not observe the entire event, we are unable to affirm that the centipede killed the treefrog or whether it already found it dead. Probably the centipede applied its poison and later began to cut the body wall of the prey. Otostigmus scabricauda poison can lead to death when injected in mice veins in laboratory conditions (Bücherl, 1946).

After observation, the specimen (centipede) was colleted and deposited in the Zoology Museum collection of USP (MZSP 843). We suppose this is the first observation of Otostigmus genus hunting vertebrates in natural conditions.

Acknowledgments - We thank CNPq for the financial support to Lucas Rodriguez Forti; to a friend, Peter Mix, for help with documentation; to Tiago Böer Breier and Luciano Mendes Castanho for comments.

\section{References}

BARROSO, E., HIDAKA, ASV., SANTOS, AX., FRANÇA, JDM., SOUSA, AMB, VALENTE, RJ. MAGALHÃES, AFA. and PARDAL, PPO., 2001. Acidentes por centopéia notificados pelo "Centro de Informações Toxicológicas de Belém", num período de dois anos. Revista da Sociedade Brasileira de Medicina Tropical, vol. 34, no. 6, p. 527-530.

BASTOS , RP. and HADDAD, CFB., 1995. Vocalizações e interações acústicas de Hyla elegans (Anura, Hylidae) durante a atividade reprodutiva. Naturalia, vol. 20, p. 165-176.

-, 1996. Breeding activity of the neotropical treefrog Hyla elegans (Anura, Hylidae). Journal of Herpetology, vol. 30, no. 3, p. 355-360.

BIAVATI, GM., WIEDERHECKER, HC. and COLLI, GR., 2004. Diet of Epipedobates flavopictus (Anura: Dendrobatidae) in a neotropical savana. Journal of Herpetology, vol. 38, no. 4, p. 510-518.

BÜCHERL, W., 1939. Quilópodos do Brasil. Mem. Inst. Butantan, vol. 23, p. 1-320.

-, 1946. Ação do veneno dos escolopendromorfos do Brasil sobre alguns animais de laboratório. Mem. Inst. Butantan, vol. 19, p. 181-198.
CARPENTER, CC. and GILLINGHAM, JC., 1984. Giant centipede (Scolopendra alternatus) attacks marine toad (Bufo marinus). Carib. J. Sci., vol. 20, p. 1-2.

CASTANHO, LM. and ROCHA, RP., 2005. Harvestmen (Opiliones: Gonyleptidae) predating on treefrogs (AnuraHylidae). Revista Ibérica de Aracnología, vol. 11, p. 43-45.

ELZINGA, RJ., 1994. The use of legs as grasping structures during prey capture and feeding by the centipede Scolopendra viridis say (Chilopoda: Scolopendridae). Journal OfThe Kansas Entomological Society, vol. 64, no. 4, p. 369-372.

FORMANOWICZ, Jr., DR., STEWART, MM., TOWNSEND, K., POUGH, FH. and BRUSSARD, PF., 1981. Predation by giant crab spiders on the Puerto Rican frog Eleutherodactylus coqui. Herpetologica, vol. 37, no. 3, p. 125-129.

FROST, DR., 2004. Amphibian species of the world: an online reference. Available in: <http://research.amnh.org/herpetology/ amphibia/index.html.>. [Accessed: april/20/2006].

KNYSAK, I., MARTINS, R. \& BERTIM, C. R. 1998. Epidemiological aspects of centipedes (Scolopendromorphae: Chilopoda) bites registered in greater S. Paulo, SP, Brazil. Rev. Saúde Pública, vol. 3, no. 6, p. 514-518.

LOSOS, JB., ANDREWS, RM., SEXTON, OJ. and SCHULER, AL., 1991. Behavior, ecology, and locomotor performance of the giant anole, Anolis frenatus. Caribbean Journal of Science, vol. 27 , no. 3-4, p. 173-179.

MACHADO, G. and CHAGAS-JÚNIOR, A., 2002. Three new cases of possible maternalism in neotropical centipedes (Chilopoda: Scolopendromorpha). Entomological News, vol. 113 , no. 1 , p. $37-40$.

MACHADO, G., 2000. Maternal care in the neotropical centipede Otostigmus scabricauda (Chilopoda: Scolopendromorpha). Entomological News, vol. 111, no. 4, p. 250-254.

MCCORMICK, S. and POLIS, GA., 1982. Arthropods that prey on vertebrates. Biological Review, vol. 57, p. 29-58.

MENIN, M., RODRIGUES, DJ. and AZEVEDO, CS., 2005. Predation on amphibians by spiders, (Arachnida, Aranae) in the Neotropical region. Phyllomedusa, vol. 4, no. 1, p. 39-47.

MOLINARI, J., GUTIÉRREZ, EE, ASCENÇÃO, AA., NASSAR, JM., ARENDS, A. and MÁRQUEZ, RJ. 2005. Predation by giant centipedes, Scolopendra gigantea, on three species of bats in a venezuelan cave. Caribbean Journal of Science, vol. 41, no. 2, p. 340-346.

MORELLATO, LPC. and HADDAD, CFB. 2000. Introduction: The brazilian atlantic forest. Biotropica, vol. 32, no. 4b, p. 786-792.

SANTOS, EM., ALMEIDA, AV. and VASCONCELOS, SD. 2004. Feeding habits of six anuran (Amphibia: Anura) species in a rainforest fragment in northeastern Brazil. Iheringia, Sér. Zool., vol. 94, no. 4, p. 433-438.

STANCAMPIANO, AJ. and CAIRE, W. 1995. Food habits of Peromyscus and Reithrodontomys in Wichita Mountains Wildlife Refuge, Oklahoma. Proc. Okla. Acad. Sci. vol. 75, p. 45-49.

TOLEDO, LF. 2003. Predation on seven south american anuran species by water bugs (Belostomatidae). Phyllomedusa, vol. 2, no. 2 , p. $105-108$. 